$\begin{array}{ccc}\text { Tersedia online di: http://ejournal-balitbang.kkp.go.id/index.php/jppi } & \text { JURNAL } \\ \text { e-mail:jppi.puslitbangkan @ gmail.com } & \text { PENELITIAN } \\ \text { PERIKANAN } & \text { INDONESIA } \\ \text { JURNAL PENELITIANPERIKANANINDONESIA } & \text { Volume 23 Nomor 2 Juni 2017 } \\ \text { e-ISSN: 2502-6542 } & \\ \text { Nomor Akreditasi: 653/AU3/P2MI-LIPI/07/2015 }\end{array}$

\title{
KEPADATAN DAN DISTRIBUSI UKURAN IKAN NAPOLEON (Cheilinus undulatus) DI PERAIRAN KARANG BUTON DAN WAKATOBI, SULAWESI TENGGARA
}

\section{DENSITY AND SIZE DISTRIBUTION OF HUMPHEAD WRASSE (Cheilinus undulatus) IN REEF WATERS OF BUTON AND WAKATOBI, SOUTHEAST SULAWESI}

\author{
Isa Nagib Edrus*1 dan Kris Handoko ${ }^{2}$ \\ 'Balai Riset Perikanan Laut, Komplek Raiser Jalan Raya Bogor km 47Nanggewer Mekar, Cibinong Bogor, \\ Jawa Barat, Indonesia-16912 \\ 2Balai Pengelolaan Sumberdaya Pesisir dan Laut, Jl. Makmur Dg. Sitakka No.129, Maros, \\ Sulawesi Selatan Indonesia-90511 \\ Teregistrasi I tanggal: 02 Februari 2017; Diterima setelah perbaikan tanggal: 11 Oktober 2017; \\ Disetujui terbit tanggal: 07 November 2017
}

\section{ABSTRAK}

Kajian tentang ukuran populasi ikan napoleon (Cheilinus undulatus) merupakan bagian dari upaya pengelolaan sumberdaya ikan rawan punah. Penelitian ikan napoleon dilaksanakan di perairan karang Kabupaten Buton (2014) dan Wakatobi (2016). Tujuan penelitian untuk mengidentifikasi kepadatan populasi napoleon dan distribusi frekuensi panjang ikan napoleon. Metode pengambilan data yang digunakan adalah Underwater Visual Census (UVC) dengan alat bantu GPS-ploating Kit sebagai penentu luas area sensus. Jumlah individu ikan napoleon yang ditemukan dalam satuan luas area sensus dihitung sebagai kepadatan. Hasil penelitian menunjukkan bahwa kepadatan ikan napoleon di Buton dan Wakatobi masing-masing 0,76 dan 0,93 individu /ha. Nilai kepadatan ikan napoleon masuk kategori kritis dengan tingkat kepadatan sedang. Ukuran ikan anakan napoleon cukup banyak di Buton (26\%) dan ukuran dewasa terbanyak (100\%) dijumpai di Wakatobi, yaitu antara $30-50 \mathrm{~cm}$. Ukuran ini termasuk dalam ukuran terlarang panen.

Kata Kunci: Kepadatan; napoleon; Buton; Sulawesi Tenggara

\section{ABSTRACT}

Assessing the population sizes of humphead warasse (Cheilinus undulatus) is vital to manage an endangered fish resource. This research aims to examine the population density and length distribution. This study was carried out at reef waters of Buton (2014) and Wakatobi (2016). A method used in data colection is underwater vicual census (UVC). The GPS-ploating Kid used as additional tool to record sensus areas. Results show that densities of humphead warasse in Buton and Wakatobi were 0.76 and 093 individual per hectar, respectively. The status was critical and a fair density level. In Buton domined by juvenile (15) valued about $26 \%$. While, in Wakatobi domined by larger size $(30$ to $50 \mathrm{~cm}$ ). However, both size was forbidden for exploiding.

Keywords: Density; humphead wrasse; Buton; Southeast Sulawesi 


\section{PENDAHULUAN}

Penelitian mengenai sediaan ikan napoleon di perairan Indonesia baru dimulai sekitar 2005 atas inisiatif para ahli "grouper \& wrasse specialist". Penelitian populasi ikan napoleon di perairan Indonesia tersebut adalah program IUCN, meliputi wilayah Madura, Nusa Tenggara Timur, Bunaken dan Raja Ampat (Sadovy et al., 2003 ; Sadovy et al., 2007; Gillett, 2010).

Menurut Sadovy et al. (2003), distribusi keberadaan ikan napoleon cukup luas di perairan karang tropis, dengan tingkat kepadatan umumnya sangat rendah. Hasil monitoring populasi ikan napoleon di beberapa perairan Indonesia menunjukkan kelimpahan antara 0,4-0,86 ekor /Ha (Edrus \& Suman, 2013).

Perhatian pemerintah atas perikanan napoleon selama ini sangat rendah, terlihat dari tidak tercatatnya produksi perikanan napoleon dengan baik, yang disebabkan hasil tangkapan ikan napoleon lebih sering diterima pengusaha ekspotir di laut. Pengelolaan perikanan napoleon seperti ini sebagai akibat tumpang tindihnya regulasi, lemahnya koordinasi dan penegakan hukum. Pengelolaan perikanan napoleon di Indonesia akhirnya masuk pada situasi yang disebut IUU Fishing (Edrus \& Suman, 2013).

Pada 2004 ikan napoleon masuk daftar merah CITES dengan status Appendiks 2, yaitu termasuk kelompok ikan rawan punah yang dalam tata aturan perdagangan dunia dibatasi oleh kuota perdagangan (IUCN, 2004). Aturan CITES menghendaki adanya tata cara pengambilan di alam yang tidak merugikan (nondetrimental finding-NDF) sebagai mana diamanatkan oleh Code of Conduct for Responsible Fishing Tahun 1995 Pasal 7.5, untuk melakukan kehati-hatian pengambilan di alam. Untuk alasan itu, kuota produksi menjadi suatu keharusan dan dibutuhkan banyak data tentang populasi ikan napoleon menurut periode waktu (temporal) dan wilayah (spasial).

Permasalahan perikanan napoleon adalah menyangkut kegagalan pengelolaan pada masa lalu, seperti rendahnya aktivitas penelitian yang menyangkut kelimpahan ikan napoleon dan kelemahan tata aturan pengelolaannya (Edrus, 2013). Rekomendasi penangkapan tidak dapat dianjurkan tanpa status kelimpahan yang jelas, karena kuota perdagangan sangat bergantung pada data ukuran populasi, baik yang dihimpun secara nasional maupun regional. Sampai saat ini masih banyak wilayah perairan yang tidak jelas pola dan sifat pengelolaan ikan napoleon, karena ketidak sediaan basis data yang merupakan suatu keharusan untuk menjamin kelestariannya. Data yang dibutuhkan management autority perikanan adalah terutama berhubungan dengan kepadatan dan ukuran siap panen. Seperti diketahui Kepmen KP No 37 Tahun 2013 telah mengatur pembatasan ukuran panen.

Pengertian kehati-hatian menangkap dan mengolah yang harus sepadan dengan tingkat pelestarian sumberdaya yang diperkirakan, serta peningkatan dalam kapasitas selanjutnya harus ditahan jika produktivitas sumberdaya sudah sangat tidak pasti. Kehatian-hatian juga harus fokus pada ketidak-pastian yang bertalian dengan ukuran dan produkstivitas ikan, titik rujukan, kondisi stok menurut referensi rujukan tersebut, tingkat dan persebaran mortalitas penangkapan dari kebijakan input perikanan. Kehati-hatian penangkapan akhirnya dinisbahkan juga pada kebutuhan akurasi data dan cara memperoleh data, karena data perikanan merupakan salah satu kunci sukses dari perikanan yang berkelanjutan (Suseno, 2007). Survei napoleon di Kabupaten Buton dan Wakatobi dengan metode UVC bertujuan mengidentifikasi ukuran populasi ikan napoleon, terutama tingkat kepadatan dan distribusi frekuensi panjang, dimana data ini diharapkan dapat digunakan untuk tujuan pengelolaan.

\section{BAHAN DAN METODE Lokasi Penelitian}

Kegiatan penelitian populasi ikan napoleon dilakukan di perairan Kabupaten Buton Provinsi Kendari pada Desember 2014 dan Kabupaten Wakatobi pada Nopember 2016. Lokasi survei di Buton meliputi Kecamatan Wabula di beberapa desa seperti Wasuemba, Wabula, Wasampela dan Koholimbo Jaya dan Kecamatan Pasar Wajo di Takimpo, Dongkala dan Kondowa (Gambar 1). Lokasi survei di Wakatobi meliputi P. Wangi-wangi, Karang Kapota, P. Kaledupa, P. Lentea, P. Tomia dan P. Tolanda (Gambar 2). Penelitian populasi ikan napoleon ini dilakukan terhadap populasi ikan semua ukuran, sehingga lokasi pengamatan difokuskan di terumbu karang bagian tepi dan tubir karang dekat lereng terumbu yang terjal dan landai. tubir terumbu (reef crest buffer zones) merupakan lokasi dimana paling mudah menjumpai ikan napoleon berukuran besar dan anakan napoleon yang naik ke atas (Oddone, 2010).

\section{Pengenalan Terhadap Ikan Napoleon di Bawah Air}

Pergerakan ikan napoleon umumnya terbatas, ikan-ikan yang berukuran besar sering berenang 
sampai $1 \mathrm{~km}$ jauhnya, sementara yang berukuran kecil umumnya memiliki daerah toritorial sendiri dan jarang pergi jauh dari wilayahnya, bahkan anakan napoleon jarang pergi jauh dari relung ekologisnya (Sadovy et al., 2003). Pada perairan jernih ikan napoleon masih bisa terlihat dengan jelas sampai dengan kedalaman 20 meter (Gambar 3). Perairan karang di Buton dan
Wakatobi umumnya jernih dengan batas pandang vertikal lebih dari $25 \mathrm{~m}$. Ikan ini sangat mudah dikenali dan dibedakan dengan jenis-jenis ikan karang lain, karena memiliki ciri-ciri khusus (Gambar 4) dan gerakannya yang lambat memudahkan pencacah untuk mengambil data.

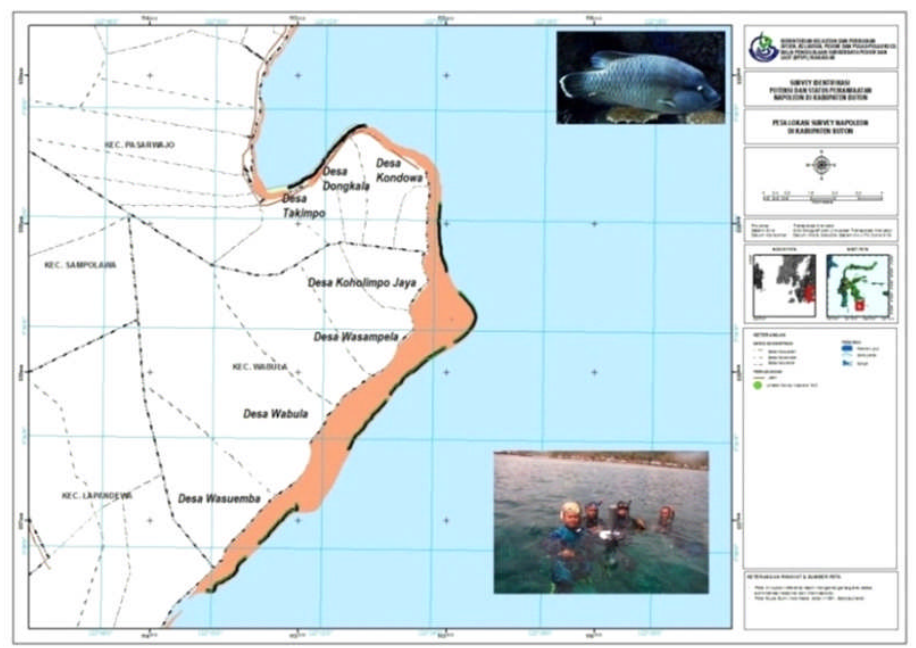

Gambar 1. Posisi lintasan sensus visual bawah air di Kecamatan Wabula dan Kecamatan Pasar Wajo, Kabupaten Buton, Sulawesi Tenggara.

Figure 1. Tracking position of underwater visual cencus in Wabula and Pasar Wajo districts, Buton County, Southeast Sulawesi.

Seperti diketahui bahwa ikan napoleon bukan tergolong ikan kriptik (tersembunyi), seperti kebanyakan kerapu, pada saat mencari makan ikan ini naik ke perairan dangkal di sekitar tubir karang (reef cresh) dan ketika berpapasan dengan penyelam ikan ini menghindar perlahan sampai kemudian masuk perairan dalam di lereng tubir. Ketika ikan napoleon melarikan diri, pencacah akan kembali menemukan ikan ini di tempat yang sama beberapa saat kemudian (Edrus \& Suman, 2013). Ikan napoleon bersifat diurnal, mencari makan pada siang hari, dan biasanya naik ke area rataan terumbu mengikuti air pasang pada pagi atau sore hari. Pada malam hari ikan ini masuk ke dalam goa atau celah-celah batu hanya untuk beristirahat tanpa aktivitas makan (Thaman, 1998 ; Lieske \& Myers, 2001).

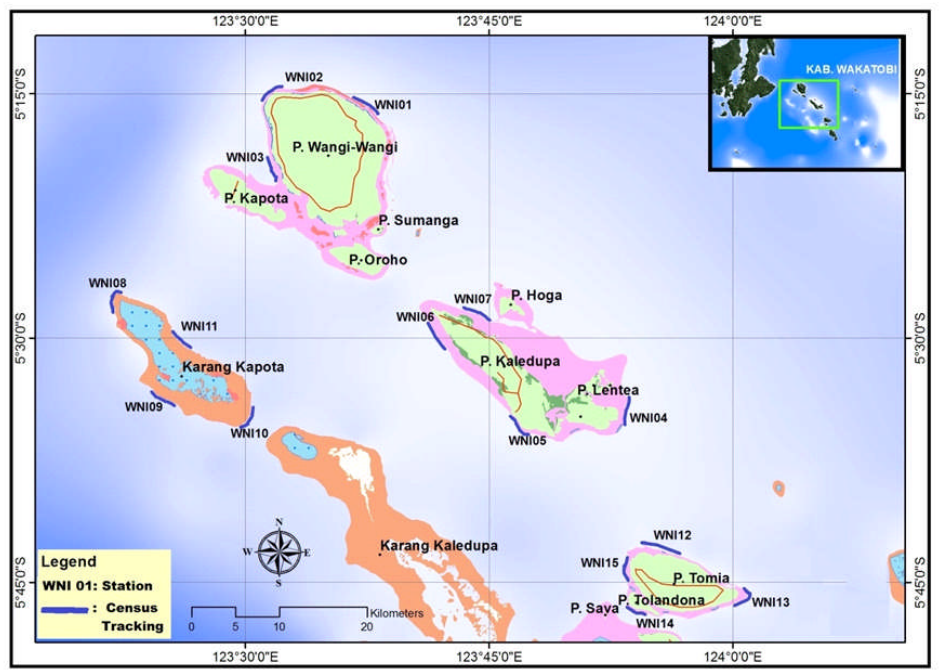

Gambar 2. Posisi lintasan sensus visual bawah air di perairan karang Kabupaten Wakatobi, Sulawesi Tenggara. Figure 2. Tracking position of underwater visual cencus in the reef waters of Wakatobi County, Southeast Sulawesi. 


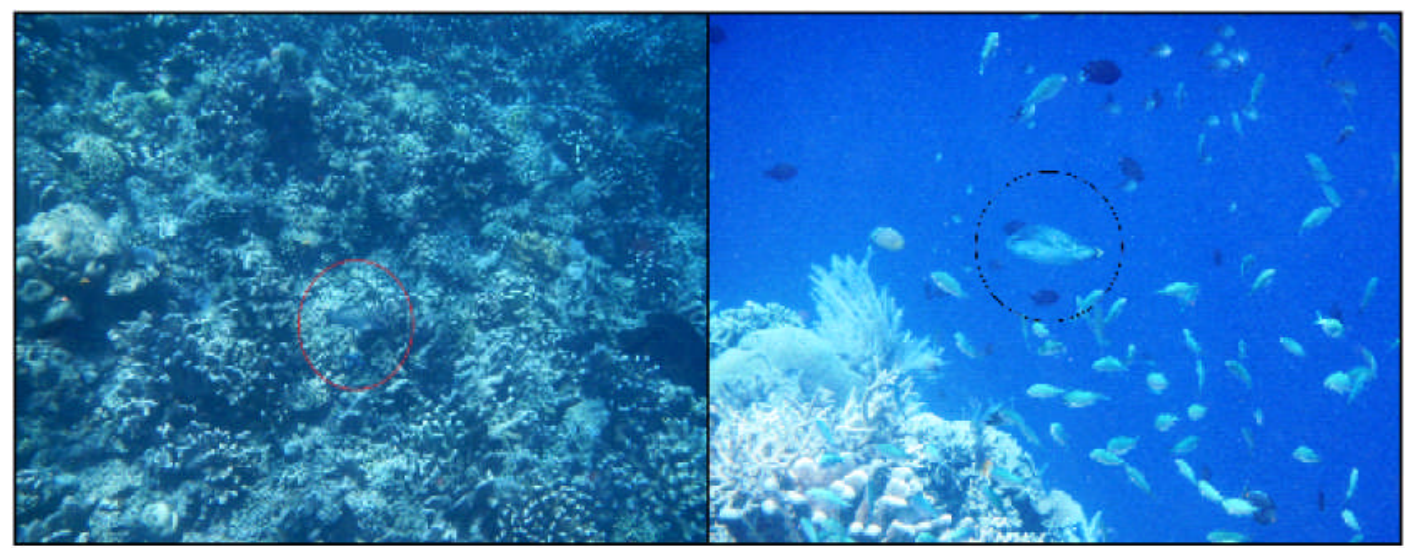

Gambar 3. Ikan napoleon (Cheilinus undulatus) di habitatnya.

Figure 3. A napoleon wrasse (Cheilinus undulatus) in its habitat.

Ukuran napoleon sekitar 10 dan $25 \mathrm{~cm}$ TL kriptik. Ikan napoleon berukuran antara $70 \mathrm{~cm}-100$ umumnya dijumpai di atas terumbu karang, bukan di bawah terumbu bersembunyi, karena ikan seukuran ini sampai ukuran dewasa bukan bersifat meliang atau $\mathrm{cm}$ ditemukan pada kedalaman lebih dari 20 meter (Edrus \& Suman, 2013).
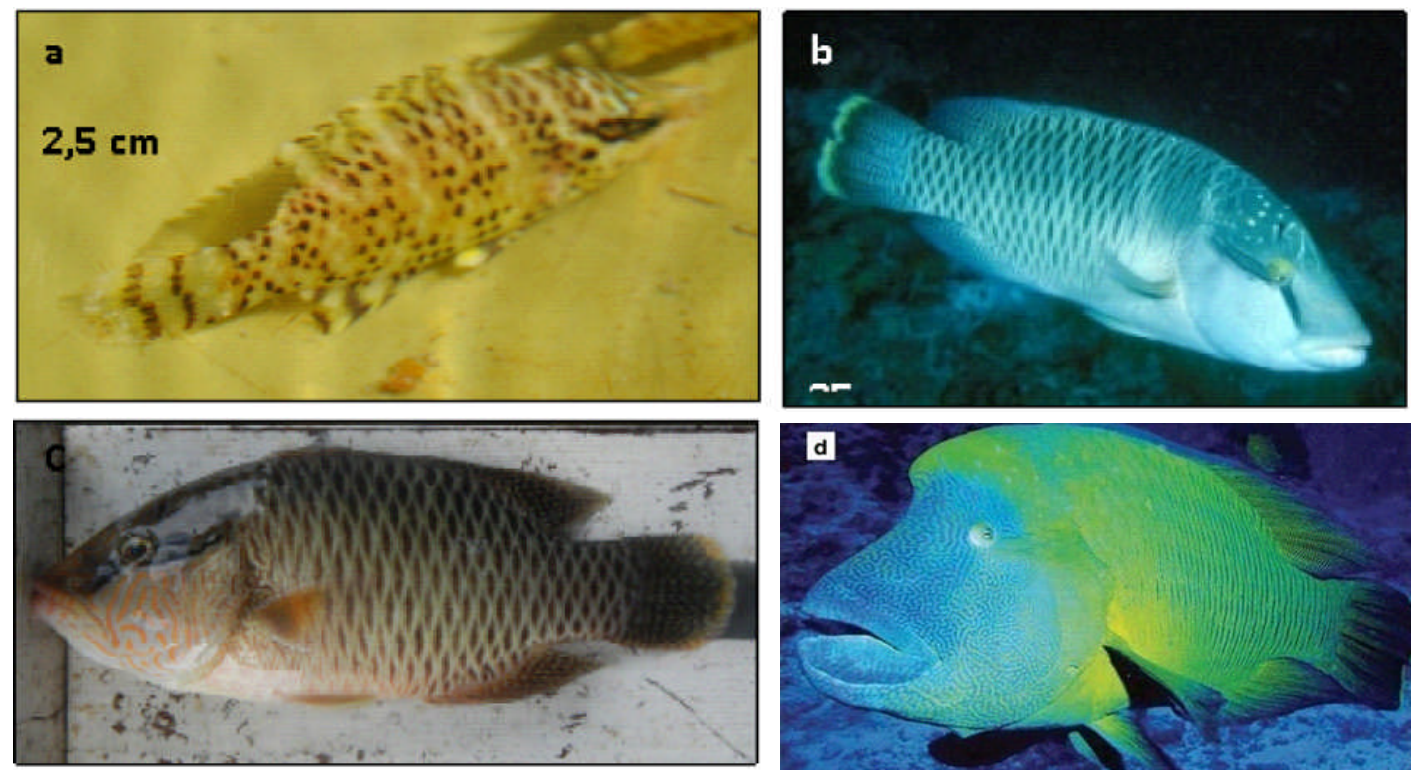

Gambar 4. Ikan napoleon (Cheilinus undulatus), a). anakan, b). dewasa, c). dewasa ukuran layak tangkap, dan d) umur tua panjang lebih dari $50 \mathrm{~m}$.

Figure 4. Napoleon wrasse (Cheilinus undulatus), a) juvenile, b) adult, c) adult for harvesting size, and d) oldest with over $50 \mathrm{~cm}$ length.

\section{Pengumpulan Data}

Pengumpulan data lapangan dilakukan dengan pendekatan Underwater Visual Census (UVC), yaitu teknik yang dirancang untuk menghitung tingkat kepadatan dari ikan yang secara relatif jarang dijumpai namun sebarannya cukup luas di terumbu karang seperti Cheilinus undulatus (Colin, 2006), dimana pengamat membawa/menyeret GPS-Floating Kit sambil berenang (snorkling). Selama snorkling, pengamat melakukan perhitungan jumlah ikan yang ditemukan pada jarak pandang 7 meter kanan dan 7 meter kiri dan selalu mencatat waktu penemuannya (jam, menit dan detik) (Colin, 2006).

Rekaman otomatis GPS untuk posisi geografis diatur setiap 30 detik, sehingga setiap kejadian penemuan ikan akan terekam posisi ordinatnya sesuai dengan jam penemuannya. Oleh karena itu pengamat menggunakan jam underwater yang waktunya telah disamakan dengan waktu (jam, menit, detik) yang tertera di GPS. Data yang terekam dalam GPS diunduh (download) dengan software dari Garmin Map Source World Map. 
Untuk setiap individu ikan napoleon yang tersensus, panjang total ikan dalam air ditaksir secara kasar dengan memperhatikan bias kaca masker $( \pm$ $30 \%$ ) dan dikelompokkan ke dalam kelas panjang kelipatan 5, 10, 15, $20 \mathrm{~cm}$, dan seterusnya (Wilson \& Green, 2009). Kelompok juvenil umumnya berukuran di bawah $15 \mathrm{~cm}$. Kelompok dewasa berukuran antara $15-50 \mathrm{~cm}$. Kelompok tua berukuran lebih besar dari $50 \mathrm{~cm}$ (Sadovy et al, 2003).

\section{Analisa Data}

Langkah setelah melakukan pengumpulan data adalah menyusunnya kedalam bentuk tabulasi. Data GPS hasil unduhan untuk selanjutnya dikerjakan dengan Microsoft Excel. Data tersebut memperlihatkan lintasan (tracking) yang bersambung setiap 30 detik sesuai dengan jalur-jalur yang terbentuk selama pengamat berenang (distance feet). Dengan mengetahui data panjang lintasan yang terhitung oleh GPS dan lebar pandangan sensus di kanan dan kiri, maka luas area sensus dapat ditentukan.

Kepadatan ikan diperoleh dengan jalan membagi jumlah ikan yang ditemukan dengan luas area sensus, sehingga satuannya manjadi individu / Ha. Luas area sensus adalah total panjang lintasan dikalikan dengan lebar pandangan kanan kiri dari pencacah. Satuan luas semula saat dikerjakan dengan kaidah "microsoft excel" melalui jalan kumulatif adalah dalam meter persegi, namun hasil perhitungan dalam meter tersebut dapat dikonversi ke dalam hektar ( $\mathrm{Ha})$. Distribusi frekuensi panjang ikan napoleon disajikan dalam bentuk grafik batang untuk menganalisa komposisi ukuran.

\section{HASIL DAN BAHASAN Hasil}

Sensus visual sepanjang beberapa lintasan di perairan karang Kabupaten Buton (17,8 km) dan Wakatobi (13,4 km) masing-masing mendapatkan 19 ekor dan 18 ekor ikan napoleon. Lintasan sensus di Buton melalui beberapa wilayah administratif kecamatan Wabula (desa Wasuemba, Wabula, Wasampela dan desa Koholimbo Jaya) dan Kecamatan Pasar Wajo (desa Takimpo, Dongkala dan Kondowa) (Gambar 1). Lintasan sensus di Wakatobi melalui wilayah Pulau Wangi-wangi, Karang Kapota, P. Kaledupa, Pulau Lentea, P. Tomia dan P. Tolanda (Gambar 2). Hasil sensus pada kedua perarian tersebut diringkas dalam Tabel 1.

Tabel 1. Hasil sensus visual ikan napoleon di Kabupaten Buton 2014 dan Wakatobi 2016 Table 1. Results of napoleon fish visual census in Counties of Buton 2014 and Wakatobi 2016

\begin{tabular}{|c|c|c|c|c|c|c|c|c|c|}
\hline \multirow{2}{*}{\multicolumn{2}{|c|}{$\begin{array}{c}\text { KAB. BUTON } \\
\text { POSISI GEORAFIS } \\
\text { Geographical Position }\end{array}$}} & \multirow{3}{*}{$\begin{array}{c}\text { Luas Area } \\
\text { Kumulatif } \\
\text { Commulative } \\
\text { Area Wides } \\
\left(\mathrm{m}^{2}\right)\end{array}$} & \multicolumn{2}{|c|}{$\begin{array}{c}\text { Cheilinus undulatus } \\
\text { Napoleon Wrasse }\end{array}$} & \multicolumn{2}{|c|}{$\begin{array}{l}\text { KAB. WAKATOBI } \\
\text { POSISI GEORAFIS }\end{array}$} & \multirow{3}{*}{$\begin{array}{c}\text { Luas Area } \\
\text { Kumulatif } \\
\text { Commulative } \\
\text { Area Wides } \\
\left(\mathrm{m}^{2}\right)\end{array}$} & \multicolumn{2}{|c|}{$\begin{array}{c}\text { Cheilinus undulatus } \\
\text { Napoleon Wrasse }\end{array}$} \\
\hline & & & Jumlah & Ukuran & Geograp & cal Position & & Jumlah & Ukuran \\
\hline & & & $\frac{\text { Numbers }}{\text { (ekor) }}$ & $\begin{array}{c}\text { Sizes } \\
(\mathrm{cm})\end{array}$ & Latitude & Longitutde & & $\frac{\text { Numbers }}{\text { (ekor) }}$ & $\begin{array}{l}\text { Sizes } \\
(\mathrm{Cm})\end{array}$ \\
\hline$-5,60188$ & 122,87517 & 2035,5 & 1 & 40 & $5,25880^{\circ}$ & $123,61592^{\circ}$ & 21102,2 & 2 & $40 ; 50$ \\
\hline$-5,58492$ & 122,88788 & 33907,2 & 1 & 45 & $5,24558^{\circ}$ & $123,53102^{\circ}$ & 42204,5 & 2 & $25 ; 40$ \\
\hline$-5,58169$ & 122,8907 & 40798,7 & 1 & 45 & $5,32671^{\circ}$ & $123,52916^{\circ}$ & 61306,5 & 2 & $35 ; 40$ \\
\hline$-5,57763$ & 122,89555 & 50984,5 & 1 & 15 & $5,57290^{\circ}$ & $123,88911^{\circ}$ & 79010,2 & 2 & 30 \\
\hline$-5,57324$ & 122,9013 & 62493,1 & 1 & 15 & $5,58765^{\circ}$ & $123,77818^{\circ}$ & 95038,7 & 1 & 35 \\
\hline$-5,57983$ & 122,89255 & 67400,4 & 1 & 30 & $5,49132^{\circ}$ & $123,69283^{\circ}$ & 110286,1 & 4 & 30 \\
\hline$-5,56993$ & 122,90671 & 79660,1 & 1 & 50 & $5,47769^{\circ}$ & $123,74009^{\circ}$ & 125522,8 & 0 & \\
\hline$-5,54843$ & 122,90378 & 106296 & 1 & 20 & $5,45952^{\circ}$ & $123,37215^{\circ}$ & 139747,4 & 0 & \\
\hline$-5,55037$ & 122,90456 & 144611,1 & 1 & 30 & $5,55739^{\circ}$ & $123,41154^{\circ}$ & 152246,3 & 0 & \\
\hline$-5,53469$ & 122,90142 & 147675 & 1 & 25 & $5,58737^{\circ}$ & $123,51150^{\circ}$ & 163329,0 & 3 & $30(2) ; 45(1)$ \\
\hline$-5,62652$ & 122,8526 & 170538,6 & 1 & 15 & $5,50076^{\circ}$ & $123,42885^{\circ}$ & 173312,4 & 1 & 45 \\
\hline$-5,64634$ & 122,83225 & 187475,2 & 2 & $15 ; 30$ & $5,71600^{\circ}$ & $123,91976^{\circ}$ & 181282,6 & 1 & 30 \\
\hline$-5,64556$ & 122,83447 & 193078 & 1 & 15 & $5,76552^{\circ}$ & $124,01106^{\circ}$ & 188011,4 & 0 & \\
\hline$-5,52311$ & 122,8575 & 216450 & 1 & 35 & $5,77897^{\circ}$ & $123,89748^{\circ}$ & 192588,0 & 0 & \\
\hline$-5,52226$ & 122,85909 & 217299,5 & 2 & $40 ; 65$ & $5,74051^{\circ}$ & $123,89191^{\circ}$ & 194136,4 & 0 & \\
\hline$-5,52208$ & 122,85943 & 249305,2 & 2 & $30 ; 60$ & & & & & \\
\hline \multicolumn{2}{|c|}{ Jumlah Total (Ekor) } & & 19 & & & & & 18 & \\
\hline \multicolumn{2}{|c|}{$\begin{array}{l}\text { Luas Total Area Sensus } \\
\text { (Ha) }\end{array}$} & 24,9 & & & & & 19,4 & & \\
\hline \multicolumn{2}{|c|}{ Kepadatan (ekor/ha) } & & 0,76 & & & & & 0,93 & \\
\hline
\end{tabular}

\section{Kepadatan}

Kepadatan ikan napoleon di wilayah perairan karang Kabupaten Buton dalam wilayah 24, 9 hektar adalah 0,76 ekor/Ha., sedangkan kepadatan di perairan karang Kabupaten Wakatobi 0,93 ekor/Ha untuk wilayah sensus seluas 19,4 hektar.

\section{Distribusi Frekuensi Panjang}

Dari estimasi ukuran panjang ikan napoleon ditemukan tiga kelompok umur, yaitu kelompok anakan (juvenile), kelompok dewasa dan kelompok dewasa tua (Gambar 5). Ukuran anakan yang ditemukan di Buton adalah $15 \mathrm{~cm}$ yang jumlahnya 26 
$\%$ dari 19 ekor dan ukuran dewasa antara $20-50 \mathrm{~cm}$ sebanyak $73 \%$. Ukuran ikan napoleon di Wakatobi yang ditemukan terbanyak (100\%) adalah ukuran dewasa, dengan kisaran antara $25-50 \mathrm{~cm}$. Ukuran terbanyak ini merupakan ukuran layak ditangkap, namun justru terlarang penangkapannya oleh Kepmen KP No. 37 Tahun 2013, sedangkan ukuran layak tangkap yang tersedia di alam dan diperbolehkan untuk di tangkap baik di Buton maupun di Wakatobi hanya berkisar pada jumlah $10 \%$ dari total jumlah individu untuk ukuran antara $40-50 \mathrm{~cm}$. Dewasa tua yang berukuran $60 \mathrm{~cm}$ sampai dengan $65 \mathrm{~cm}$ dijumpai hanya di Buton, yaitu $\pm 1 \%$ (Gambar 5$)$.

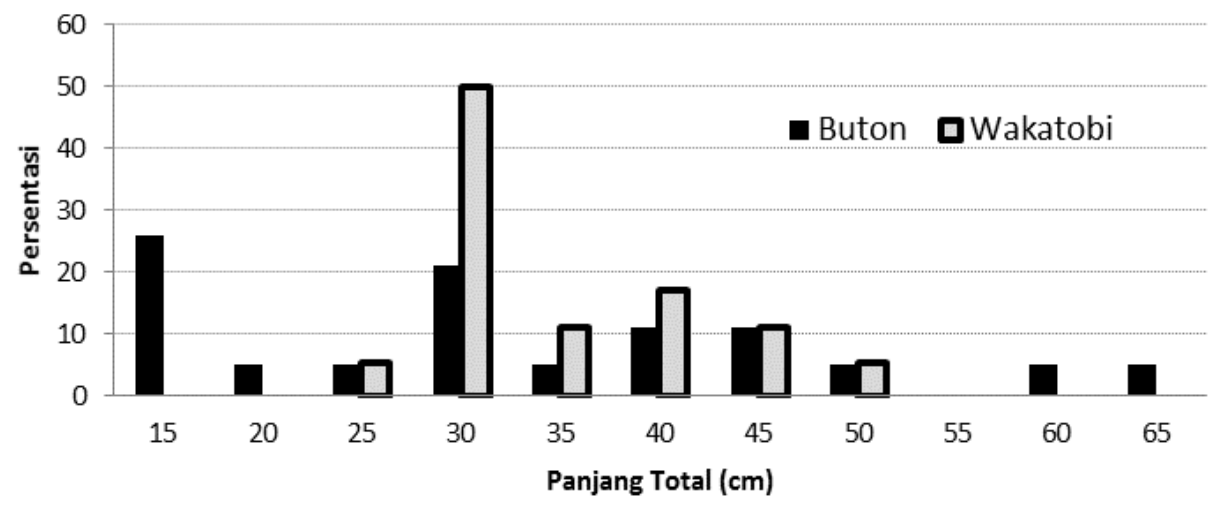

Gambar 5. Distribusi frekuensi panjang ikan napoloen yang dijumpai di perairan, Kabupaten Buton dan Wakatobi, Sulawesi Tenggara.

Figure 5. Length frequency distribution for napoleon observed in the waters of Buton and Wakatobi, Southeas Sulawesi.

\section{Bahasan}

Tingkat kepadatan yang bervariasi dari 0,76 ekor/ Ha dan 0,93 ekor/Ha di Buton dan Wakatobi termasuk kategori kepadatan "sedang" dan masih berada pada tingkat kategori populasi napoleon yang "kritis" (Edrus, 2013). Kondisi populasi ikan napoleon di perairan Indonesia umumnya memang di antara kategori "kritis" sampai dengan "masih rentan dan mulai membaik" (Edrus, 2013), seperti ditemukan di perairan Derawan yang memiliki kepadatan populasi 0,13-0,9 ekor/ Ha dengan lintasan sensus $13 \mathrm{~km}$ dan $6,5 \mathrm{~km}$ (BPSPL Kalbar, 2013; 2014), serta Bunaken dan Karas FakFak yang masing-masing memiliki kepadatan 1,71 dan 1,41 ekor/Ha dengan lintasan sensus 19,26 km dan $32 \mathrm{~km}$ (Edrus et al., 2014). Hasil penelitian lain yang terlihat luar biasa adalah hasil monitoring di perairan Kepulauan Sembilan, Sinjai, dan Takabonerate, Sulawesi Selatan (Rahman \& Syam, 2015). Pada Marempu, Sinjai, didapat 6,3 ekor/Ha untuk wilayah jelajah sensus 1,7 ha, dan pada Bungimpare didapat 5,5 ekor/Ha untuk wilayaj jelajah sensus 0,9 ha, serta pada Makodang 0,8 ekor/Ha untuk wilayah jelajah 1,3 ha. Hasil penelitian di Takabonerate juga didapat kepadatan yang tinggi dari biasanya, yaitu antara 0,48 - 4,17 ekor/Ha untuk wilayah jelajah sensus 12 km (Rahman \& Syam, 2015). Hasil penelitian di wilayah Sinjai dan Takabonerate tersebut kurang dapat diperbandingkan dengan beberapa hasil penelitian di atas, karena pendekatan yang berbeda dalam hal jelajah sensus yang sesungguhnya.
Secara alami sifat populasi ikan napoleon adalah rendah di semua jenis perairan, baik pada perairan yang berstatus tingkat eksploitasi rendah, sedang atau tinggi maupun pada perairan yang masih alami dan bahkan pada daerah konservasi dan area yang memang menjadi habitat kesukaannya (Gillet, 2010).

Rekruitmen dalam pengertian usaha perikanan, yaitu tersedianya ikan ukuran layak tangkap, umumnya mendorong eksploitasi sumberdaya perikanan. Perairan Buton dan Wakatobi adalah termasuk wilayah pemanfaatan perikanan karang. Wakatobi merupakan sentra pengumpul ikan napoleon (Edrus \& Suman, 2013). Jumlah ketersediaan ikan napoleon ukuran panen di Buton maupun di Wakatobi (Gambar 5) dibatasi oleh adanya aturan penangkapan (Kepmen KP No. 37 Tahun 2013) dan ukuran layak tangkap yang tersisa hanya berkisar pada $10 \%$ dari kepadatannya. Resiko penurunan populasi menjadi mungkin terjadi jika penangkapannya terus berlangsung, karena kepadatan di dua lokasi ini tergolong "sedang" dari kategori kepadatan yang bersifat "kritis" untuk eksploitasi. Menurut informasi dari pedagang dan nelayan di Indonesia (Sadovy et al., 2013), bahwa laju tangkap yang terus menurun menjadi bukti tentang populasi napoleon yang terus terancam. Laju tangkap dapat terpelihara dalam nilai yang memadai hanya dengan berpindah-pindahnya area penangkapan atau meluaskan wilayah tangkap. Hal ini menunjukkan bahwa perikanan napoleon memiliki 
resiko deplesi sumberdaya yang berantai (Sadovy et al., 2013). Pengelolaan sumberdaya napoleon di perairan Kabupaten Buton dan Wakatobi perlu lebih mempertimbangkan adanya usaha-usaha pengumpul di sekitarnya.

Pola pemanfaatan ikan napoleon dapat diasumsikan dari ketersediaan interval-interval ukuran panjang tubuh dalam distribusi frekuensi ikan napoleon yang berbeda antara Buton dan Wakatobi (Gambar 5). Ikan napoleon yang tergolong umur anakan paling banyak dijumpai di Buton, sementara ukuran dewasa dijumpai lebih banyak di Wakatobi. Dewasa tua yang berukuran $60 \mathrm{~cm}$ sampai dengan $65 \mathrm{~cm}$ dijumpai di Buton pada 2014, sedangkan di Wakatobi tidak teridentifikasi pada 2016. Fenomena sebaran panjang seperti ini menunjukkan bahwa adanya kecenderungan retruitmen dalam pengertian ekologi yang menyediakan anakan napoleon lebih banyak dan kemudian tumbuh berkembang menyediaakan ukuran dewasa muda, yaitu ukuran siap panen $(30-50 \mathrm{~cm})$ yang biasa disebut rekruitmen ukuran pengelolaan perikanan. Ukuran dewasa tua yang besarnya melebihi $60 \mathrm{~cm}$ biasanya menurun dalam jumlahnya, sebagai pengaruh dari perikanan tangkap seiring waktu, dimana di Buton ukuran dewasa tua masih dijumpai pada 2014 tetapi di Wakatobi pada tahun 2016 ukuran lebih dari $60 \mathrm{~cm}$ tidak dijumpai lagi, karena waktu akan lebih berpengaruh terhadap besaran ukuran populasi (jumpah individu) pada wilayah intensitas penangkapan yang tinggi. Jadi pola distribusi frekuensi panjang ikan napoleon seperti itu (Gambar 5) adalah indikasi dari adanya pertumbuhan populasi yang diikuti oleh intensitas penangkapan yang tinggi (Sadovy et al., 2007).

Hasil wawancara yang dilakukan terhadap masyarakat pemerhati konservasi ikan karang dengan nelayan ( $N=40$ ) pada 2004 di Sulawesi dan Maluku menyebutkan bahwa dimana saja ikan napoleon menjadi target tangkapan, ikan ini telah menjadi menurun jumlah populasinya dalam rentang waktu 10 - 15 tahun terakhir ((IUCN, 2006), tetapi jika ikan ini pemanfaatannya menurun maka ikan ini masih terlihat kembali dan kadang-kadang menjadi target tangkapan lagi. Kecuali itu, banyak hasil tangkapan terakhir ini justru dari ukuran juvenil yang langsung bisa dijual atau dibesarkan dalam keramba (IUCN, 2006). Hal ini menunjukkan bahwa kondisi stok ikan napoleon saat ini tidak lepas dari pola eksploitasi tahun-tahun sebelumnya, dimana perlu menjamin tersedianya ukuran-ukuran yang dapat meneruskan generasi populasinya.

Perkembangan populasi ikan napoleon juga berkaitan dengan lingkungan hidupnya, dalam hal ini bagaimana bentuk habitatnya, yaitu area dimana ikan napoleon meneruskan generasi. Area seperti itu tentu saja tidak semata-mata bergantung pada besarnya tutupan karang, tetapi area terumbu karang memenuhi syarat untuk tempat memijah, merawat anakan, mencari makan dan menghindar dari bahaya (Tupper, 2007). Survei kesehatan terumbu karang di Buton oleh COREMAP-CTI (2013) menunjukkan status kesehatan karang "sedang" sampai "baik" dengan rata-rata tutupan karang hidup 48,33\%, karang lunak $4,13 \%$, spon $0,17 \%$, alga $25 \%$, DCA $15,27 \%$ dan sisanya berupa abiotik. Survei yang sama di Wakatobi oleh COREMAP-CTI (2016) menunjukkan status kesehatan karang tergolong "baik", dengan tutupan karang hidup $25,71 \%$, karang lunak $15 \%$, spon $2,49 \%$, DCA $33,64 \%$ dan sisanya termasuk abiotik. Kondisi kesehatan ditentukan menurut persentasi karang batu (Chau, 1998). Menurut Tupper (2007) bahwa kelimpahan ikan napoleon lebih bergantung pada relif substrat terumbu dibanding tutupan karang batu dalam memenuhi syarat habitat, dimana ikan napoleon biasa ditemukan, seperti area lereng karang, tubir (reef crest dan reef wall) dan lekuk kanal dengan bentuk bentik terumbu biotik dan abiotik yang beragam (coral reef benthic lifeform). Kondisi seperti itu adalah habitat napoleon yang teridentifikasi pada lintasan sensus di Buton maupun di Wakatobi (Colin, 2010; Russell, 2004). Ikan napoleon juga sering dijumpai pada area karang yang rusak (Edrus \& Suman, 2013), seperti di perairan Maratua Kabupaten Berau (Edrus et al., 2013) dan perairan pulau Kadatua Taman Laut Bunaken (Edrus et al., 2014), namun memiliki dinding terumbu dengan celah pelindung (shelter) untuk ikan menghindar dari gangguan (Oddone et al., 2010).

Hasil survei, seperti juga yang penah dilakukan di Maratua Berau, Bunaken dan Karas Fak-Fak (Edrus et al., 2013 : 2014) menunjukkan bahwa area terumbu karang yang dijumpai ikan napoleon cukup tinggi adalah area dasar perairan yang berupa campuran antara karang (biotik) dan pasir (abiotik). Kondisi seperti itu juga ternyata lebih umum dijumpai di periran Desa Takempo Kecamatan Pasar Wajo dan Wasuemba serta Wasampela Kecamatan Wabula, Kabupaten Buton dan perairan Kaledupa bagian Barat dan Karang Kapota bagian Tenggara, dimana dijumpai ikan napoleon relatif banyak dari lokasi penelitian di desa lain. Pada tiga desa tersebut Napoloen dijumpai 3 sampai 5 ekor. Hal ini berkaitan dengan pola ikan napoleon dalam mencari makanan kegemarannya, dimana ikan napoleon menyukai ikan gobid/blenid, kekerangan, anakan kepiting (krustacea), bulu babi atau bintang laut, dan belut laut yang semuanya lebih umum dijumpai di dasar berpasir (Choat et al., 2006; Sadovy et al., 2010). 


\section{KESIMPULAN}

Status populasi ikan napoleon di perairan Kabupaten Buton dan Wakatobi tergolong pada kategori kritis dengan tingkat kepadatan sedang (masing-masing 0,76 dan 0,93 ekor/Ha). Populasi ikan napoleon dalam kondisi berkembang yang ditandai oleh banyaknya ukuran anakan dan dewasa muda, sebaliknya minimnya populasi ikan napoleon dengan ukuran besar memberikan indikasi adanya tingkat pemanfaatan yang tinggi terhadap ikan ini pada tahuntahun sebelumnya. Perairan Kecamatan Wabula Buton, seperti juga perairan bagian Barat Kaledupa dan Tenggara Karang Kapota - Wakatobi, perlu segera mendapat perlindungan dengan ditetapkan sebagai zona konservasi. Monitoring populasi ikan napoleon perlu dilakukan secara berkala dan perlu juga memantau area yang lain, dimana wilayah kepulauan Buton masih sangat luas.

\section{PERSANTUNAN}

Tulisan ini merupakan kontribusi dari kegiatan monitoring populasi ikan napoleon 2014 dan 2016 di Kabupaten Buton dan Wakatobi yang terselenggara atas kerjasama COREMAP - CTI - KKP dan Balai Pengelolaan Sumberdaya Pesisir dan Laut, Maros.

\section{DAFTAR PUSTAKA}

BPSPL Kalbar. (2013). Potensi Ikan Napoleon (Cheilinus undulatus) di Pulau Maratua Kabupaten Berau, Provinsi Kalimantan Timur (p. 29). Pontianak, Indonesia: KKP - Balai Pengelolaan Sumberdaya Pesisir Publ.

BPSPL Kalbar. (2014). Kelimpahan Ikan Napoleon (Cheilinus undulatus) di Pulau Maratua Kabupaten Berau, Provinsi Kalimantan Timur (p. 32). Pontianak, Indonesia: KKP - Balai Pengelolaan Sumberdaya Pesisir dan Laut Publ.

Chau, L.M. (1998). Status of Southeast Asian Coral Reefs. In: Status of Coral Reefs of the World: 1998. (p. 79). C. Wilkinson (Ed). Quensland, Australia: Sida - Australian Institute of Marine Science - ICLARM Publ..

Colin, P.L. (2006). Underwater visual census of Cheilinus undulatus (humphead wrasse, Napoleon fish) in three areas of Indonesian waters, 2005. Annex II. In Development of fisheries management tools for trade in humphead wrasse, Cheilinus undulatus, in compliance with Article IV of CITES. (p. 47). Final Report CITES Project 2006 No. A-
254. (p.47). Sadovy (Ed). Roma, Italy: Convention on the International Trade in Endangered Species, AC22 Inf. 5.

Colin, P.L. (2010). Aggregation and spawning behaviour of the humphead wrasse Cheilinus undulates (Pisces: Labridae): general aspects of spawning behaviour. Jour. of Fish Biol. 76, 987-1007.

COREMAP-CTI. (2013). Monitoring Kesehatan Terumbu Karang dan Ekosistem Terkait Kabupaten Buton Sulawesi Tenggara 2013 (p. 109.). Y. Yuti (Ed). Jakarta, Indonesia: P2O - LIPI Publ.

COREMAP-CTI. (2016). Monitoring Kesehatan Terumbu Karang dan Ekosistem Terkait Kabupaten Wakatobi Sulawesi Tenggara 2013 (p. 98.). Y. Yuti (Ed). Jakarta, Indonesia: P2O - LIPI Publ.

Edrus, I.N. (2013). Penilaian Kepadatan Populasi Ikan Napoleon (Cheilinus undulatus, Ruppell 1835) Dalam Kaitannya dengan Kepentingan Pengelolaan di Indonesia. J. Kebijak. Perikan. Ind. , 4(2), 79 - 84.

Edrus, I.N. \& Suman, A. (2013). Ikan Napoleon, Cheilinus undulatus Ruppell 1835, Status Stok dan Pengelolaannya di Indonesia (p. 185). Bogor, Indonesia: Penerbit IPB.

Edrus, I.N., Yusma, M.I., Ricky, Junaidi, S.J. \& Seputro, H. (2013). Kepadatan Populasi dan Habitat Ikan Napoleon (Cheilinus undulatus) di Perairan Karang Pulau Maratua, Kabupaten Berau, Kalimantan Timur. Dalam Status Pemanfaatan Sumberdaya Daya Ikan di Perairan Laut Sulawesi. (p. 25-38). A. Suman, Wudianto, G. Bintoro dan J. Haluan (Eds). Bogor, Indonesia: IPB Press.

Edrus, I.N., Suharti, S.R. \& Y. Sadovy. (2014). Status populasi ikan napoleon di wilayah Taman Nasional Bunaken dan Kabupaten Karas Fak-Fak. Jur. Pen. Perikan. Ind. Vol. 20 (2), 113-119.

Gillett, R. (2010). Monitoring and Management of the Humphead Wrasse, Cheilinus undulatus. In FAO Fisheries and Aquaculture Circular No. 1048. (62 pp). Roma, Italy: FAO Publ.

IUCN. (2004). CITES priority: humphead wrasse and the Thirteenth Meeting of the Conference of the Parties to CITES. In IUCN, TRAFFIC and WWF briefing document. Bangkok, Thailand: IUCN. 
IUCN (2006). Development of fisheries management tools for trade in humphead wrasse, Cheilinus undulatus, in compliance with Article IV of CITES. In Final Report CITES Project 2006 No. A-254.(103 $\mathrm{pp})$. Sadovy (Ed). Roma, Italy: Convention on the International Trade in Endangered Species, AC22 Inf. 5.

Lieske, E. \& Myers, R. (1997). Reef Fishes of the World. (p. 452) Jakarta, Indonesia: Periplus Edition.

Oddone, A., Onori, R., Carocci, F., Sadovy, Y., Suharti, S., Colin, P.L. \& Vasconcellos, M. (2010). Estimating Reef Habitat Coverage Suitable for the Humphead Wrasse, Cheilinus undulatus, Using Remote Sensing. In FAO Fisheries and Aquaculture Circular No. 1057 FIRF/C1057 (En). (37 pp). Rome, Italy: FOOD AND AGRICULTURE ORGANIZATION OF THE UNITED NATIONS.

Rahman, A. \& Syam, A.R. (2015). Pemetaaan Sebaran dan Kelimpahan Ikan Napoleon Cheilinus undulatus di Teluk Maumere, Kepulauan Sembilan dan Takabonerate. Jurnal Aquatika. 6, 49 - 58.

Russell, B. (2004). Cheilinus undulatus. In IUCN 2013. IUCN Red List of Threatened Species. (Version 2013.1.) < www.iucnredlist.org $>$. Downloaded on 26 August 2013.

Sadovy, Y., Kulbicki, M., Labrosse, P., Letourneur, Y., Lokani, P. \& Donaldson, T.J. (2003). The humphead wrasse, Cheilinus undulatus: Synopsis of a threatened and poorly known giant coral reef fish. Reviews. Fish Biology and Fisheries 13(3), 327-364.

Sadovy, Y., Punt, A. E., Cheung, W., Vasconcellos, M., Suharti, S. \& Mapstone, B. D. (2007). Stock assessment approach for the napoleon fish, Cheilinus undulatus, in Indonesia. A tool for quotasetting for data-poor fisheries under CITES Appendix II non-detriment finding requirements. In FAO Fisheries Circular No. 1023. (p. 71). Rome, Italy: FAO.

Suseno. (2007). Menuju Perikanan Berkelanjutan. (p. 161). Jakarta, Indonesia: Penerbit Pustaka Cidesindo.

Thaman, R. (1998). Our endangered Variivoce. Weekend Nature, Fiji Times 10/1/98: 4-5.

Tupper, M. (2007). Identifiacation of Nursery Habitat for Commercially Valuable Humphead Wrasse, Cheilinus undulatus, and Large Grouper (Pisces: Serranidae) in Palau. Mar. Ecol. Prog. Ser., 332: $189-199$.

Wilson, J.R. \& Green, A.L. (2009). Metode Pemantauan Biologi Untuk Menilai Kesehatan Terumbu Karang dan Efektivitas Pengelolaan Kawasan Konservasi Laut di Indonesia (Terjemahan) - Versi 1.0. Dalam TNC Indonesia Marine Program Report 1(09), 46 hal. 